\title{
Acclimation of sea-ice microalgae to freezing temperature*
}

\author{
M. Rochet ${ }^{1}$, L. Legendre ${ }^{1} \&$ S. Demers ${ }^{2}$ \\ ${ }^{1}$ Département de biologie, Université Laval, Québec, Québec G1K 7P4, Canada \\ ${ }^{2}$ Centre Champlain des Sciences de la Mer, Ministère des Pêches et des Océans, P.O. Box 15500, 901 Cap Diamant, Québec, Québec G1K 7Y7, \\ Canada
}

\begin{abstract}
The potential impact of temperature on maximum photosynthetic rate was investigated for natural populations of sea-ice microalgae in Hudson Bay. A distinctive psychrophilic acclimation, caused by seasonally increasing light intensities, developed as a response to the increasing sensitivity of photosynthesis to low temperature. In the meantime, there was a seasonal decrease in species diversity, which suggests that the survival of sea-ice microalgae at freezing temperature and under conditions of seasonally increasing light intensity is dependent upon their ability to develop a mechanism of protection against freezing.
\end{abstract}

Survival of sea-ice microalgae depends on their ability to grow at in situ low irradiance and temperature. Several species of Antarctic diatoms are extremely shade-adapted and obligately psychrophilic in their temperature responses (Bunt 1968). The temperature at the sea-ice interface is constant and depends only on the salinity of the sea water, which determines the freezing point. A similar temperature constancy is observed in hot water sources (Brock 1967a, b). The extreme low temperature at the ice-water interface (ca $-1.0^{\circ} \mathrm{C}$ ) is a mirror-image of the extreme high temperatures encountered by microorganisms in hot water sources (ca $60^{\circ} \mathrm{C}$ ). Under extremely hot conditions the microalgae show optimum growth at the environmental temperature, which suggests that they are optimally acclimated to the in situ temperature. Experimental studies on sea-ice microalgae indicate that temperature acclimation is an important factor in determining species succession and community structure at extreme low temperature (Bunt 1964, Bunt \& Lee 1970). Although it is not known whether, or to what extent, net photosynthesis is limited by low temperature, at

\footnotetext{
- Contribution to the program of GIROQ (Groupe interuniversitaire de recherches océanographiques du Québec)
}

the low light intensities prevailing under sea ice, net carbon fixation by microalgae from the sea-ice habitat is markedly temperature dependent particularly in the range -1.5 to $+5^{\circ} \mathrm{C}$ (Bunt 1964).

In order to assess whether microalgae growing in environmental extreme conditions are acclimated to these conditions, physiological responses to controlled variations of the variable considered must be measured on populations sampled from the natural environment. We examined the changes in photosynthetic rate of the sea-ice microalgae after short-term exposures to different temperatures. We present evidence consistent with the idea that a psychrophilic acclimation has developed, so as to enhance the ability of the surviving sea-ice species to photosynthesize at the ambient freezing temperature as the light intensity seasonally increases.

Sea-ice microalgae were sampled on 4 different occasions between March and May 1983 at a field station located on the first-year ice $20 \mathrm{~km}$ off Kuujjuarapik $\left(55^{\circ} 25.4^{\prime} \mathrm{N}, 7^{\circ} 52.3^{\prime} \mathrm{W}\right)$, Hudson Bay, Québec, Canada. Using a specially designed 2.01 'epontic sampler', we collected the interstitial water flowing from the ice together with the microalgae from the ice-water interface. The sample was therefore free of ice. Three $50 \mathrm{ml}$ subsamples were immediately collected in light-tight jars and acclimatized over $7 \mathrm{~h}$ to 3 different temperatures $\left(-0.5,3.0\right.$, and $\left.15.0^{\circ} \mathrm{C}\right)$. The ambient temperature at the ice-water interface remained relatively constant throughout the season (average temperature $-0.6^{\circ} \mathrm{C}$ ). As there is little information concerning the rates of microalgal photosynthesis following temperature shifts, temperature acclimatization in this study lasted $7 \mathrm{~h}$ so that the microalgae could adjust to the experimental temperatures. This is significantly shorter than the generation time of sea-ice microalgae (2.5 to $6 \mathrm{~d}$ ) (Palmisano \& 
Sullivan 1982, Van Baalen \& O'Donnell 1983), thus avoiding any long-term adaptive changes, and is consistent with the experimental approach for the study of hot-source microalgae (Brock 1967a). Every $30 \mathrm{~min}$, each jar was gently stirred. Microalgal photosynthetic rates versus irradiance in each subsample was then measured at the acclimatization temperature, using an incubator described by Lewis \& Smith (1983). Chlorophyll a concentrations corrected for phaeopigments were determined by the fluorometric method, after filtration (Whatman $\mathrm{GF} / \mathrm{C}, 25 \mathrm{~mm}$ ) of $80 \mathrm{ml}$ aliquots followed by $24 \mathrm{~h}$ extraction in $90 \%$ acetone at $0{ }^{\circ} \mathrm{C}$ without grinding (Yentsch \& Menzel 1963). The maximum photosynthesis per unit of chlorophyll $\left(\mathrm{P}_{\max }^{\mathrm{B}}\right)$, the photosynthetic efficiency $(\alpha)$, the photoinhibition parameter $(\beta)$, and the photoadaptive index $\left(I_{k}\right)$ were estimated according to the equations of Platt et al. (1980) using a Gauss-Newton algorithm (Jennrich \& Sampson 1968). Aliquots of each sample were fixed in

\section{APRIL 1983}

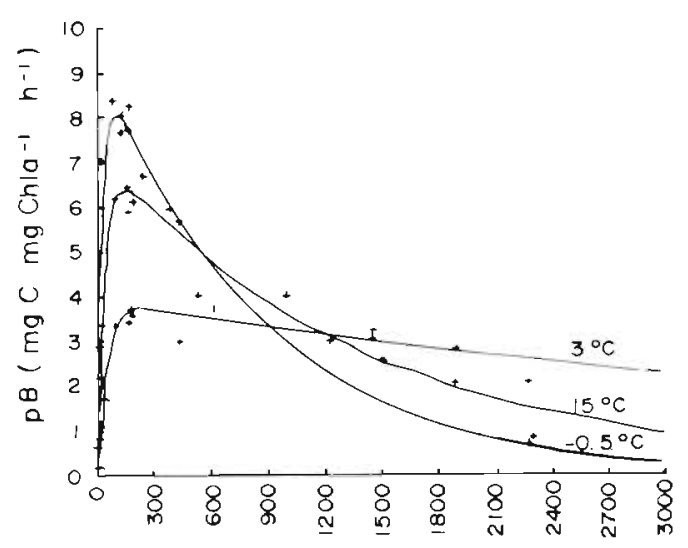

29 APRIL 1983

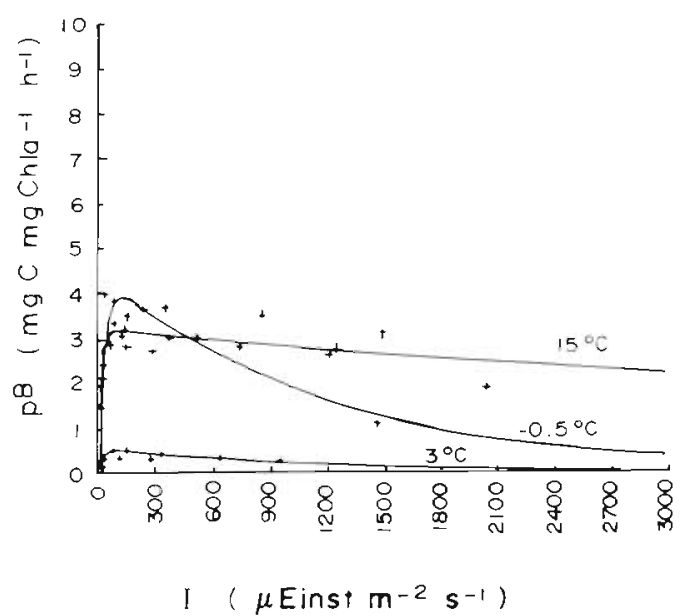

$2.5 \%$ glutaraldehyde for cell counting and identification

The $\mathrm{P}$ vs I curves for the 3 experimental temperatures show characteristic changes in photosynthesis between sampling dates $\mathrm{P}_{\max }^{\mathrm{B}}$ values were highest at $-0.5^{\circ} \mathrm{C}$ on the 4 sampling dates (Fig. 1). Results of a Friedman 2-way analysis of variance, testing the $\mathbf{4}$ sampling dates under the 3 experimental temperature conditions $\left(-0.5,3.0\right.$, and $\left.15.0^{\circ} \mathrm{C}\right)$, showed a significant effect $(p<0.05)$ of temperature on the maximum photosynthetic rate $\left(\mathrm{P}_{\max }^{\mathrm{B}}\right)$. The multiple comparison test (Conover 1980) indicated that $\mathrm{P}_{\max }^{\mathrm{B}}$ was significantly higher at $-0.5^{\circ} \mathrm{C}$ than at 3.0 and $15.0^{\circ} \mathrm{C}$, but showed no significant difference between 3.0 and $15.0^{\circ} \mathrm{C}$. This agrees with experimental data which indicate that dark reactions regulated by enzymes are temperature dependent (Yentsch 1974, Finenko 1978). There was no significant effect of temperature on the photosynthetic efficiency $(\alpha ; p=0.17)$, the photo-

\section{APRIL 1983}

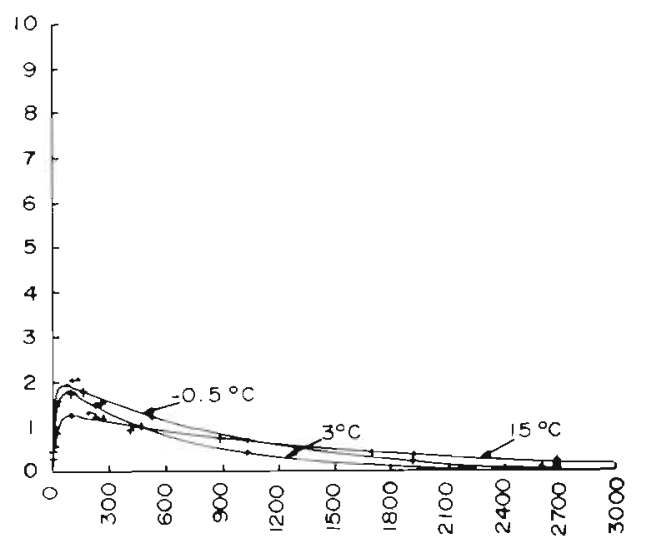

5 MAY 1983

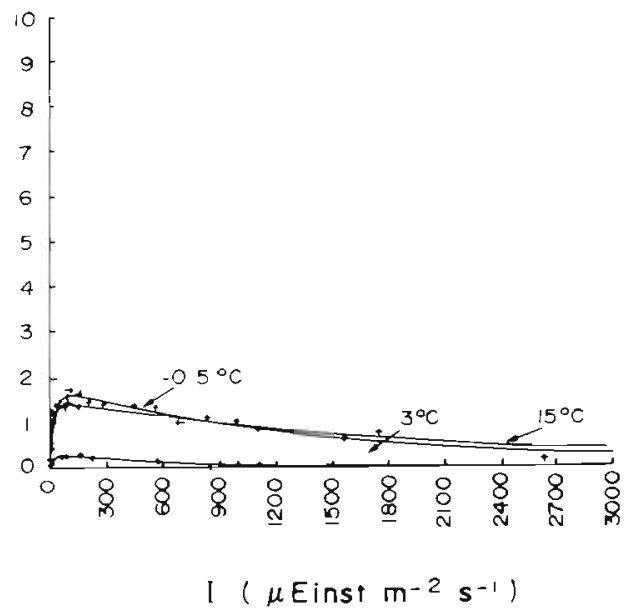

Fig. 1. Photosynthesis versus irradiance curves of sea-ice microalgae acclimatized at 3 experimental temperatures on 4 sampling dates. The highest $P_{\max }^{\mathrm{B}}$ was always observed for samples incubated at $-0.5^{\circ} \mathrm{C}$ 
inhibition parameter $(\beta ; p=0.14)$, and the photoadaptive index $\left(\mathrm{I}_{\mathrm{k}} ; \mathrm{p}=0.78\right)$. The ratio of $\mathrm{P}_{\max }^{\mathrm{B}}$ at $15.0^{\circ} \mathrm{C}$ to that at $-0.5^{\circ} \mathrm{C}$ remained relatively constant with time (Table 1), suggesting that the highest temperature was never lethal in the short term. At low light intensities $\left(10 \mu\right.$ Einstein $\mathrm{m}^{-2} \mathrm{~s}^{-1}, 10$ and $\left.20 \mathrm{Apr}\right)$, despite a drastic change in species composition (Fig. 2), there was no marked effect of temperature on photosynthesis, $\mathrm{P}_{\max }^{\mathrm{B}}$ values being similar at the 3 incubation temperatures (Table 1). As light intensity increased to $36 \mu$ Einstein $m^{-2} s^{-1}$ there was an increasing effect of temperature on the photosynthetic response (Table 1) without any

Table 1. Maximum photosynthetic rates $\left(\mathrm{P}_{\max }^{\mathrm{B}}\right)$ of sea-ice microalgae incubated at 3 experimental temperatures. Coefficients of variation (C.V.) of $\mathrm{P}_{\max }^{\mathrm{B}}$, showing that $\mathrm{P}_{\max }^{\mathrm{B}}$ was similar at the 3 temperatures on 10 and 20 April, and that there was an increased effect of temperature on $\mathrm{P}_{\max }^{\mathrm{B}}$ for the last 2 sampling dates. Right hand column: ratio of $\mathrm{P}_{\max }^{\mathrm{B}}$ at $15^{\circ} \mathrm{C}$ and $-0.5^{\circ} \mathrm{C}$

\begin{tabular}{|crrrrr|}
\hline $\begin{array}{c}\text { Sampling } \\
\text { dates }\end{array}$ & \multicolumn{5}{c}{ Maximum photosynthetic rate $\left(\mathrm{P}_{\max }^{\mathrm{B}}\right)$} \\
& $-0.5^{\circ} \mathrm{C}$ & $3^{\circ} \mathrm{C}$ & $15^{\circ} \mathrm{C}$ & $\mathrm{C} . \mathrm{V}$ & $\begin{array}{c}15^{\circ} \mathrm{C} / \\
-0.5^{\circ} \mathrm{C}\end{array}$ \\
\hline $10 \mathrm{Apr}$ & 8.06 & 3.93 & 6.40 & .34 & .79 \\
$20 \mathrm{Apr}$ & 1.98 & 1.83 & 1.24 & .23 & .63 \\
$29 \mathrm{Apr}$ & 3.87 & .47 & 3.19 & .72 & .82 \\
$5 \mathrm{May}$ & 1.60 & .28 & 1.36 & .65 & .84 \\
\hline
\end{tabular}

drastic change in the sea-ice population (last 2 sampling dates: Fig. 2). In the meantime, all the other environmental variables measured $2 \mathrm{~m}$ below the icewater interface (e.g. temperature, salinity, current velocity: Fig. 3) remained almost constant. The fact that microalgae respond to temperature independently from species composition, shows that the observed photosynthetic responses are not taxonomic but physiological, and are related to seasonal increase in light intensity.

When exposed to increasing light intensities up to approximately $33 \mu$ Einstein $\mathrm{m}^{-2} \mathrm{~s}^{-1}$, sea-ice microalgae in the laboratory are known to become more and more sensitive to low temperatures (Bunt 1968). We observed the same effect with natural epontic cells at $3.0^{\circ} \mathrm{C}$ (Table 1 ). However at $-0.5^{\circ} \mathrm{C}$, there is no such effect; thus the population in its natural environment $\left(-0.6{ }^{\circ} \mathrm{C}\right)$ has a photosynthetic activity which becomes more and more restricted to the ambient temperature as light intensity increases. Our results suggest that sea-ice microalgae at environmental temperature $\left(-0.6^{\circ} \mathrm{C}\right)$ have developed psychrophilic acclimation, as a protection against the increasing sensitization to the freezing ambient temperature brought about by the seasonally increasing light intensity. This acclimation would therefore account for the capacity of the population to photosynthesize at freezing temperature, even
Fig. 2. Seasonal changes in light intensity and in cumulative percentages of species at the sea-ice interface. Arrows indicate dates of the 4 temperature experiments

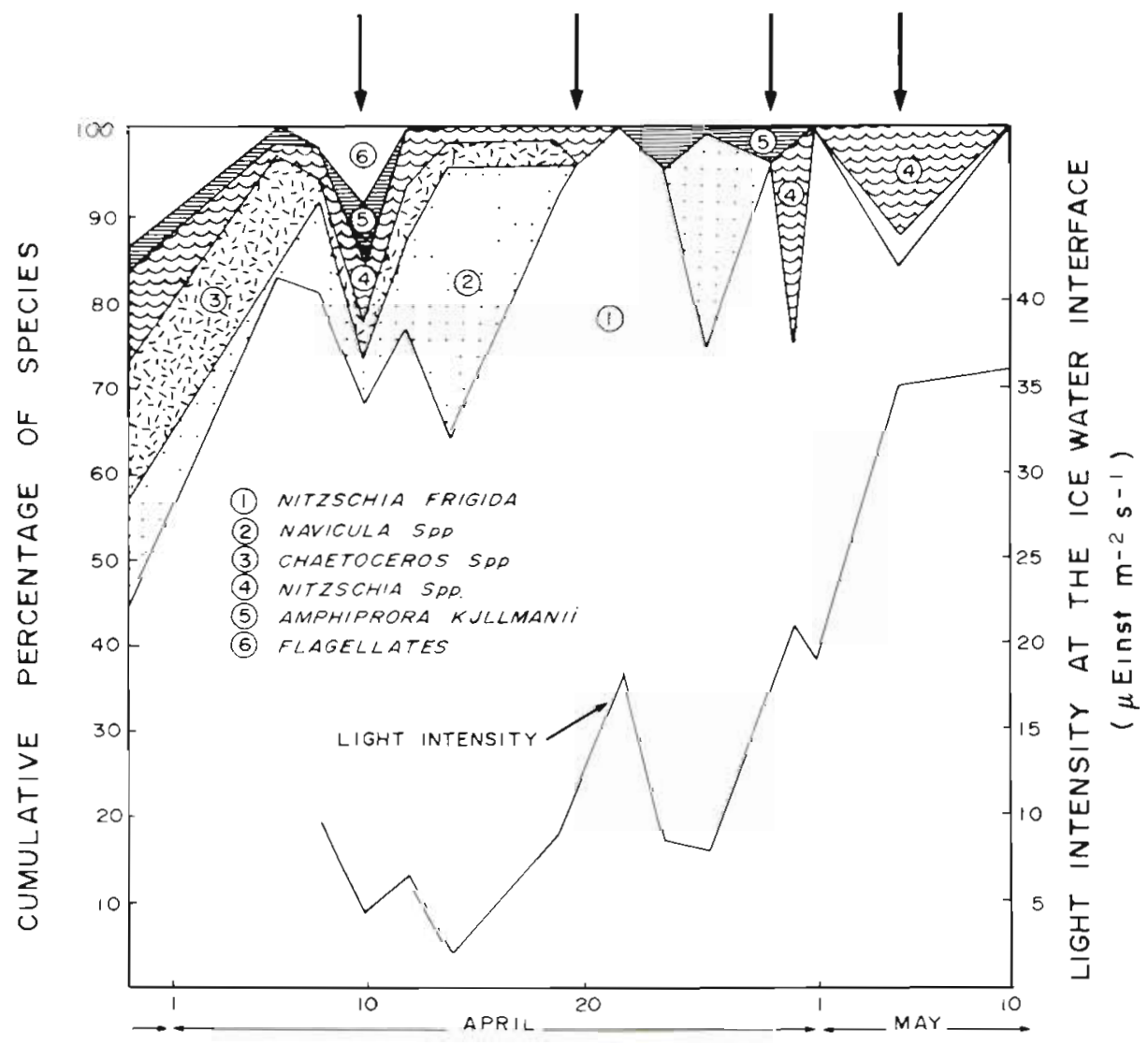




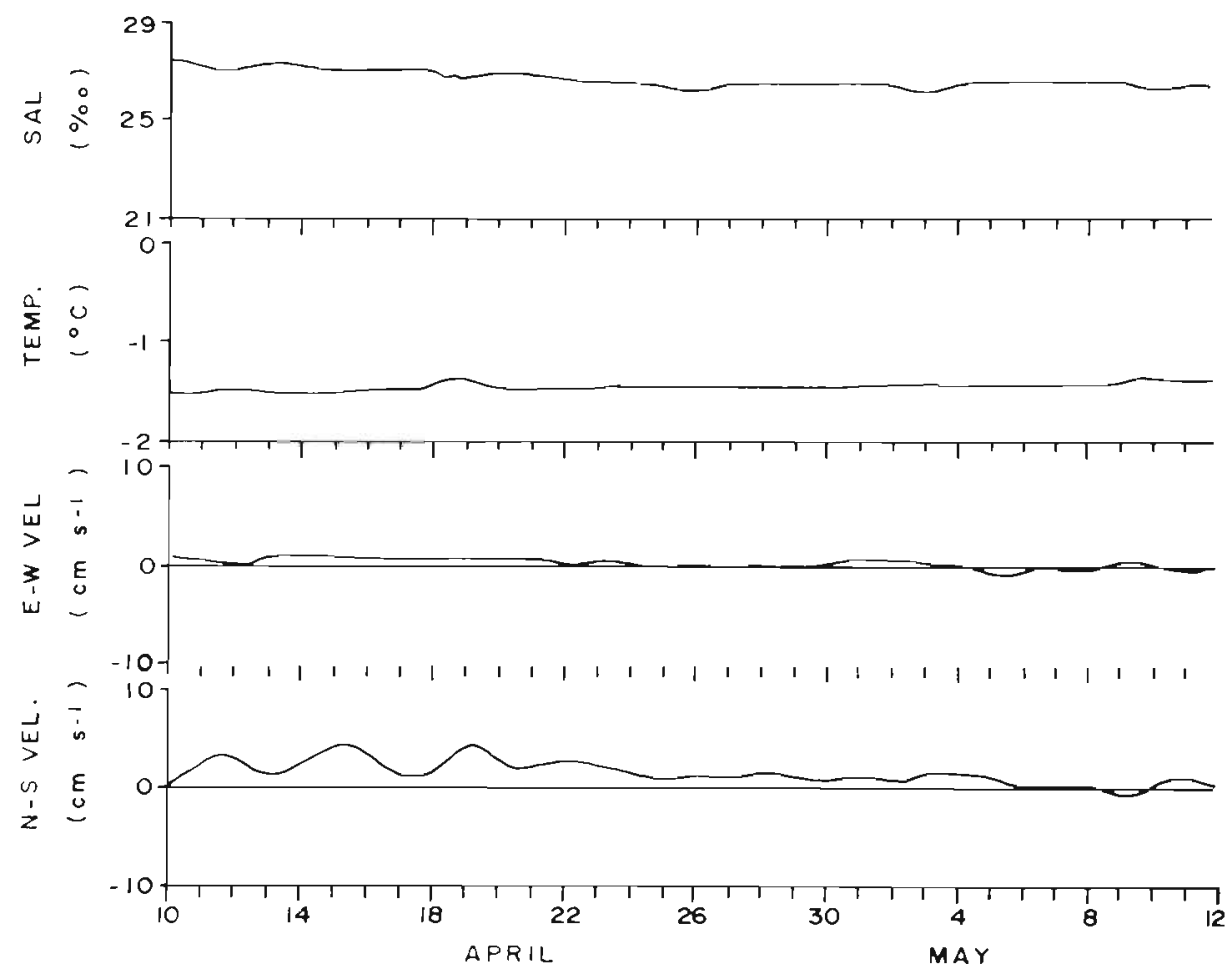

Fig. 3. Physical environment variables $2 \mathrm{~m}$ under the sea-ice interface, at the sampling station when light intensity increases. The time scale of the process (early Mar to mid May) allows for the progressive selection of species, or strains, that are more and more psychrophilically acclimated. Nitzschia frigida is the most commonly encountered species in Arctic and Antarctic: in the Beaufort Sea (Arctic) the diatoms $N$. frigida and $N$. cylindrus represent about $50 \%$ of the population (Horner \& Schrader 1982). The bottom-ice community in East Antarctica is dominated by species of Entomoneis, and N. frigida (McConville \& Wetherbee 1983). This might be related to psychrophilic adaptability as this species is almost the last one remaining in the epontic microflora of southeastern Hudson Bay in mid-May (Fig. 2).

Several mechanisms can explain the observed photosynthetic changes. A previous study on the freezing tolerance of marine unicellular algae has shown significant differences that could be attributed neither to growth conditions nor to culture age (Ben-Amotz \& Gilboa 1980). An explanation for our results is provided by Li et al. (1984), who attributed temperature acclimation of Arctic phytoplankton to an increase in RuBPC activity near freezing temperature (ca $0^{\circ} \mathrm{C}$ ), as previously observed on cultures of Phaeodactylum tricornutum by Li \& Morris (1982) at low temperature $\left(<10^{\circ} \mathrm{C}\right)$. These results are supported by the experimental findings of Morris \& Farrell (1971) who observed an increase in photosynthetic enzymes with decreasing temperature in Dunaliella, but did not observe this pattern in Phaeodactylum.
It is striking that, as the combination of environmental light and temperature becomes adverse to photosynthesis (Table 1), the sea-ice microalgae become more and more acclimated to the extremely stable ambient temperature. Similar strategies of photosynthetic microorganisms are found at both extremes of the temperature range. In both high and low temperature environments, microalgae are found to be most efficient at environmental temperature. Several mechanisms of adaptability contribute to the ability of the population to cope with unpredictability of the environment (Conrad 1983). According to Conrad, 2 mechanisms operate together. First, the induction mechanism helps the microalgae to bring about a mechanism of protection against freezing; second, there is selection among the species that have developed the acclimation. As there is no form of adaptability entirely without biological cost (Conrad 1983) continued photosynthesis at freezing temperature when light intensity increases narrows the range of temperatures within which optimum photosynthesis can occur.

Acknowledgements. This research was funded by the Natural Sciences and Engineering Research Council of Canada (strategic and individual research grants to L.L.), by the Champlain Centre for Marine Sciences and Surveys (Fisheries and Oceans), and by grants to GIROQ from the Fonds FCAC of Quebec and NSERC. Helicopter time was provided by Fisheries and Oceans and logistic support by the Société d'énergie de la Baie James. Housing was at the 
Kuujjuarapik field station of the Centre d'études nordiques Université Laval, where we benefited from the invaluable assistance of the superintendent C. Côté. We are especially indebted to $\mathrm{M}$. Dubé and A. Gagné for field assistance, to $\mathrm{L}$. Bérard-Therriault for cell enumeration, and to H. D. G. Smyth for developing the 'epontic sampler'.

\section{LITERATURE CITED}

Ben-Amotz, A., Gilboa, A. (1980). Cryopreservation of marine unicellular algae with regard to size, culture age, photosynthetic activity and chlorophyll-to-cell ratio. Mar. Ecol. Prog. Ser. 2: 157-161

Brock, T. D. (1967a). Microorganisms adapted to high temperatures. Nature, Lond. 214: 882-885

Brock, T. D. (1967b). Life at high temperatures. Science 158: 1012-1019

Bunt, J. S. (1964). Primary productivity under sea ice in Antarctic waters. Antarct. Res. Ser. 1: 13-31

Bunt, J. S. (1968). Some characteristics of microalgae isolated from Antarctic sea ice. Antarct. Res. Ser. 11: 1-14

Bunt, J. S., Lee, C. C. (1970). Seasonal primary production in Antarctic sea ice at McMurdo Sound in 1967. J. mar. Res. 28: $304-320$

Conover, W. J. (1980). Practical non-parametric statistics. Wiley, Toronto

Conrad, M. (1983). Adaptability. Plenum Press, New York

Finenko, Z. Z. (1979). Production in plant populations. In: Kinne, O. (ed.) Marine ecology, Vol. IV, Dynamics. Wiley, Chichester, p. 13-87

Horner, R., Schrader, G. C. (1982). Relative contributions of ice algae, phytoplankton and benthic microalgae to primary production in nearshore regions of the Beaufort Sea. Arctic 35: L85-503

Jennrich, R. I., Sampson, P. F. (1968). Application of stepwise regression to non-linear estimation. Technometrics 10: $63-67$
Lewis, M. R., Smith, J. C. (1983). A small volume, shortincubation-time method for measurement of photosynthesis as a function of incident irradiance. Mar. Ecol. Prog. Ser 13: 99-102

Li, W. K. W., Morris, L. (1982). Temperature adaptation in Phaeodactylum tricornutum Bohlin: photosynthetic rate compensation and capacity. J. exp. mar Biol. Ecol. 58: $135-150$

Li, W. K. W., Smith, J. C., Platt, T. (1984). Temperature response of photosynthetic capacity and carboxylase activity in Arctic marine phytoplankton. Mar. Ecol. Prog. Ser 17: $237-243$

McConville, M. J., Wetherbee, R. (1983). The bottom-ice microalgal community from annual ice in the inshore waters of East Antarctica. J. Phycol. 19: 431-439

Morris, I., Farrell, K. (1971). Photosynthetic rates, gross patterns of carbon dioxide assimilation and activities of ribulose diphosphate carboxylase in marine algae grown at different temperatures. Physiologia pl. 25: 372-377

Palmisano, A. C., Sullivan, C. W. (1982). Physiology of sea-ice diatoms. I. Response of three polar diatoms to a simulated summer-winter transition. J. Phycol. 18: 489-498

Platt, T., Gallegos, C. L., Harrisson, W. G. (1980). Photoinhibition of photosynthesis in natural assemblages of marine phytoplankton. J. mar. Res. 38: 687-701

Van Baalen, C., O'Donnell, R. J. (1983). Isolation and growth of psychrophilic diatoms from the ice-edge in the Bering Sea. J. gen. Microbial. 129: 1019-1023

Yentsch, C. S. (1974). Some aspects of the environmental physiology of marine phytoplankton: a second look. Oceanogr. mar. Biol. A. Rev. 12: 41-75

Yentsch, C. S., Menzel, D. W. (1963). A method for the determination of phytoplankton chlorophyll and phaeophytin by fluorescence. Deep Sea Res. 10: 221-231

Accepted for printing on April 4, 1985 